\title{
Productive characteristics in dairy buffalo (Bubalus bubalis) in the Eastern Amazon
}

\section{L.C. Marques ${ }^{1}$, A.S. Matos ${ }^{1}$, J.S. Costa ${ }^{1}$, C.S. Silva ${ }^{1}$, R.N.C. Camargo Júnior ${ }^{1}$, C. McManus $^{2}$, V. Peripolli ${ }^{3 *}$, C.V. Araújo ${ }^{4}$, M.M.M. Laureano ${ }^{4}$, R.L. Sales ${ }^{5}$, J.R.F. Marques ${ }^{5}$}

${ }^{1}$ Universidade Federal do Pará - Castanhal, PA

${ }^{2}$ Universidade de Brasília - Instituto de Biologia - Brasília, DF

${ }^{3}$ Instituto Federal Catarinense - Campus Araquari, SC

${ }^{4}$ Universidade Federal do Mato Grosso - Sinop, MT

${ }^{5}$ Embrapa Amazônia Oriental - Belém, PA

\begin{abstract}
The objective of this study was to determine factors affecting phenotypic characteristics related to milk production and reproductive efficiency of dairy buffalo. Phenotypic records of 2,459 Murrah, Mediterranean and crossbred buffaloes from the Embrapa Eastern Amazônia herd, from 1969 to 2013 were used. Traits included: total milk production during lactation (TMP), milk production corrected for 305 days (P305); cow weight at calving $(\mathrm{CW})$, fat milk percentage $(\mathrm{F})$, age at first calving (AFC), calving interval (CI), calf birth weight (BW), as well as lactation (LP) and service periods (SP). Most traits were affected by genetic group as well as year and season or interaction between them. Genetic group affected F, CI, SP and CW. Very young and older cows showed poorer production traits. There was interaction between season and year for F, CI and CW. Correlations traits were generally medium to low. The principal component analysis showed that higher fat milk percentage was associated with higher percentage of Murrah breed, longer lactation period and older cows. Phenotypic characteristics in buffaloes reared in the Brazilian Amazon were significantly affected by genetic and management factors. This information can be used to help build sustainable production systems for the region and guide farmer decisions.
\end{abstract}

Keywords: breeding efficiency, Mediterranean, milk production, Murrah, genetic group

\section{RESUMO}

O objetivo deste estudo foi determinar os fatores que afetam as características fenotípicas relacionadas à produção de leite e a eficiência reprodutiva de búfalas leiteiras. Foram utilizados os registros fenotípicos de 2.459 búfalas das raças Murrah, Mediterrâneo e seus cruzamentos do rebanho da Embrapa Amazônia Oriental, de 1969 a 2013. As características incluídas foram: produção total de leite durante a lactação (PTL), produção de leite corrigida para 305 dias (P305), peso da búfala ao parto (PV), percentual de gordura do leite $(G)$, idade ao primeiro parto (IPP), intervalo entre partos (IP), peso do bezerro ao nascimento (PN), assim como os períodos de lactação (PL) e de serviço (PS). A maioria das características foi afetada pelo grupo genético, bem como pelo ano e pela estação ou pela interação entre eles. O grupo genético afetou o G, IP, PS e PV. Búfalas muito jovens e mais velhas mostraram características de produção mais baixas. Houve interação entre estação e o ano para G, IP e PV. As correlações entre as características foram geralmente de médias a baixas. A análise de componentes principais mostrou que a maior porcentagem de gordura no leite foi associada com a maior porcentagem de sangue Murrah, com o maior período de lactação e com búfalas mais velhas. As características fenotípicas das búfalas criadas na Amazônia brasileira foram significativamente afetadas por fatores genéticos e de manejo. Essas

Recebido em 25 de janeiro de 2019

Aceito em 13 de agosto de 2019

*Autor para correspondência (corresponding author)

E-mail: vanessa.peripolli@hotmal.com 
informações podem ser usadas para ajudar a construir sistemas de produção sustentáveis para a região e orientar as decisões dos produtores.

Palavras-chave: eficiência reprodutiva, grupo genético, Mediterrâneo, Murrah, produção de leite,

\section{INTRODUCTION}

Buffalo farming in Brazil is seen as a cost effective alternative, since the species easily adapt to diverse environments. The production and consumption of buffalo milk has been growing due to the demand for derivatives such as cheese and butter. The high levels of fat and total solids in buffalo milk increase the yield in the manufacture of derivatives in relation to bovine milk (Rosales and Batalha, 2017).

In Brazil, buffaloes generally produce between 1,500 and 4,500 liters of milk per lactation, and have a higher productive life than the dairy cows and can live for more than 20 years. However, there are factors limiting the commercial production of buffalo milk including late age at first calving, reproductive seasonality, prolonged calving interval and the long dry period (Tonhati et al., 2000b; Ramos et al., 2006; Malhado et al., 2007; Tonhati et al., 2008; Baldi et al., 2011). In the Amazon, the buffalo is predominantly reared in extensive ecosystems on native pastures, especially on the island of Marajó, and in a few cases, on cultivated pastures where the Murrah and Mediterrâneo breeds tend to be more expressive, and, along with smaller numbers, Carabao and Jafarabadi breeds.

Although studies have been carried out in Brazil on the productive and reproductive traits of buffaloes (Tonhati et al., 2000b; Cassiano et al., 2003), there is still lack of information on this species in a wide range of ecosystems where they are reared in Brazil. The objective of this study was to determine factors affecting phenotypic characteristics related to milk production and reproductive efficiency of dairy buffaloes from Embrapa Eastern Amazon to support genetic management strategies.

\section{MATERIAL AND METHODS}

Birth records of 2,459 Murrah, Mediterranean, and crossbred animals from the Embrapa Eastern Amazon herd were used, in the period between 1969 to 2013, including information on the total milk production during lactation (TMP), cow weight at calving $(\mathrm{CW})$, fat milk percentage $(\mathrm{F})$, age at first calving (AFC), calving interval (CI), calf birth weight (BW), as well as lactation (LP) and service periods (SP). Cumulative production up to 305 days (P305) was calculated based on the lactation period (LP) and TMP according to the following formula P305 = (TMP / LP $) \times 305$.

The herd was kept in an experimental station of Embrapa Eastern Amazon, located in the metropolitan area of the Belém city in Pará State, at $01^{\circ} 27^{\prime} 21^{\prime \prime} \mathrm{S}$ and $48^{\circ} 30^{\prime} 16^{\prime \prime} \mathrm{W}$, with an altitude of $10 \mathrm{~m}$. The animals were raised in semiintensive, in situ conservation system. This location has a rainy tropical climate, with a short dry season, according to the Koppen classification. The annual mean temperature was $27.2^{\circ} \mathrm{C}$, ranging from 21.8 to $32.4^{\circ} \mathrm{C}$. The relative humidity showed an annual mean of $88 \%$ and the mean annual rainfall was around $2,537 \mathrm{~mm}$.

The total annual insolation was 2,300 hours. The soils of the region belong to the moist yellow latosols. The main diet of the animals consisted of Brachiaria and Panicum pasture. Data included animals with AFC ranging between 549 days (18 months) and 1,830 days (60 months), animals with CI ranging between 365 days (12 months) and 450 days (14 months), and animals with TMP greater than $610 \mathrm{~kg}$. Six genetic group of cows and calves with genealogical record (Mediterranean (0), Murrah (1) and 0.0625, 0.125, 0.25 and $0.5 \%$ of Murrah breeds) were considered. Two calving periods were considered, with the rainy period from January to June and a dry (or less rainy) season from July to December.

Statistical analysis included analysis of variance (PROC GLM), Pearson correlations (CORR) and factor analysis (FACTOR) using the SAS package (Statistical Analysis System, v. 9.3, Cary, North Carolina). Independent variables included sex of the offspring, genetic group of cows and calves, season, year and order of birth, as well as the interaction between them. The weight of the buffalo cow at birth was used as a covariate. 


\section{RESULTS}

Genetic group (Table 1) affected fat milk percentage $(\mathrm{F})$, calving interval $(\mathrm{CI})$, service period (SP) and cow weight at calving $(\mathrm{CW})$, with higher percentage in the Murrah breed leading to higher fat milk percentage, shorter SP and therefore CI, as well as lighter cows (Table 2). Cows calving in the rainy season tended to produce more milk (P305) (Table 1). The variation due to year (Table 1), as seen for AFC, BW, LP, TMP and P305 was expected, while an interaction between year and season was seen for F, CI and CW (Figure 1).

Table 1. Summary for variance analysis of production traits in dairy buffaloes reared in the Brazilian Amazon

\begin{tabular}{llllllllll}
\hline & $\begin{array}{l}\text { AFC } \\
(\text { days })\end{array}$ & $\begin{array}{l}\text { BW } \\
(\mathrm{kg})\end{array}$ & $\begin{array}{l}\mathrm{LP} \\
(\text { days })\end{array}$ & $\begin{array}{l}\text { TMP } \\
(\mathrm{kg})\end{array}$ & $\begin{array}{l}\mathrm{F} \\
(\%)\end{array}$ & $\begin{array}{l}\text { CI } \\
(\text { days })\end{array}$ & $\begin{array}{l}\text { SP } \\
(\text { days })\end{array}$ & $\begin{array}{l}\text { P305 } \\
(\mathrm{kg})\end{array}$ & $\begin{array}{l}\text { CW } \\
(\mathrm{kg})\end{array}$ \\
\hline $\mathrm{R}^{2}$ & 0.09 & 0.16 & 0.14 & 0.33 & 0.31 & 0.23 & 0.23 & 0.42 & 0.45 \\
$\mathrm{CV}$ & 18.24 & 7.75 & 20.92 & 20.93 & 10.83 & 26.18 & 25.60 & 15.76 & 10.47 \\
Mean & 1234.13 & 35.85 & 262.11 & 1806.76 & 6.96 & 483.99 & 90.86 & 1896.26 & 556.56 \\
$\mathrm{GG}$ & $\mathrm{ns}$ & $\mathrm{ns}$ & $\mathrm{ns}$ & $\mathrm{ns}$ & $* *$ & $*$ & $*$ & $\mathrm{~ns}$ & $* *$ \\
Order & - & $\mathrm{ns}$ & $\mathrm{ns}$ & $*$ & $\mathrm{~ns}$ & $* *$ & $*$ & $\mathrm{~ns}$ & $*$ \\
Cow weight & $\mathrm{ns}$ & $* *$ & $\mathrm{~ns}$ & $* *$ & $\mathrm{~ns}$ & $* *$ & $\mathrm{~ns}$ & $* *$ & - \\
Sex & $\mathrm{ns}$ & $* *$ & $\mathrm{~ns}$ & $\mathrm{~ns}$ & $\mathrm{~ns}$ & $\mathrm{~ns}$ & $* *$ & $\mathrm{~ns}$ & $*$ \\
GG-Calf & - & $\mathrm{ns}$ & $\mathrm{ns}$ & $\mathrm{ns}$ & $\mathrm{ns}$ & $\mathrm{ns}$ & $\mathrm{ns}$ & $\mathrm{ns}$ & $\mathrm{ns}$ \\
Season & $*$ & $\mathrm{~ns}$ & $\mathrm{~ns}$ & $\mathrm{~ns}$ & $\mathrm{~ns}$ & $\mathrm{~ns}$ & $\mathrm{~ns}$ & $*$ & $*$ \\
Year & $* *$ & $* *$ & $* *$ & $* *$ & $* *$ & $* *$ & $\mathrm{~ns}$ & $* *$ & $* *$ \\
Season*year & $\mathrm{ns}$ & $\mathrm{ns}$ & $\mathrm{ns}$ & $\mathrm{ns}$ & $* *$ & $*$ & $\mathrm{~ns}$ & $\mathrm{~ns}$ & $* *$ \\
\hline
\end{tabular}

$\mathrm{R}^{2}$ : coefficient of determination, $\mathrm{CV}$ : coefficient of variation, GG: genetic group; $\mathrm{P}^{*} \mathrm{Y}$ : interaction between period and year, AFC: age at first calving, BW: calf birth weight, LP: lactation period, TMP: total milk production during lactation, F: fat milk percentage, CI: calving interval, SP: service period, P305: milk production corrected for305 days, CW: cow weight at calving, ns: not significant, $*$ : $\mathrm{P}<0.05, * *: \mathrm{P}<0.001$.

Table 2. Main environmental effects of production traits in dairy buffaloes reared in the Brazilian Amazon

\begin{tabular}{|c|c|c|c|c|c|c|c|c|c|}
\hline Genetic Group & AFC (days) & $\mathrm{BW}(\mathrm{kg})$ & LP(days) & TMP(kg) & $\mathrm{F}(\%)$ & CI(days) & SP(days) & P305 (kg) & $\mathrm{CW}(\mathrm{kg})$ \\
\hline 0 & 1238.78 & 36.44 & 269.25 & 1958.28 & $6.50^{\mathrm{c}}$ & $543.98^{\mathrm{a}}$ & $103.81^{\mathrm{a}}$ & 2098.05 & $565.89^{\mathrm{a}}$ \\
\hline 0.0625 & 1273.23 & 36.18 & 264.78 & 2051.64 & $5.53^{\mathrm{d}}$ & $487.38^{\mathrm{bc}}$ & $93.03^{\mathrm{ab}}$ & 2046.74 & $563.04^{\mathrm{ab}}$ \\
\hline 0.125 & 1234.67 & 35.85 & 248.43 & 1711.25 & $6.97^{\mathrm{bc}}$ & $459.17^{\mathrm{cd}}$ & $90.16^{\mathrm{b}}$ & 1954.96 & $558.57^{\mathrm{ab}}$ \\
\hline 0.25 & 1226.90 & 35.56 & 260.34 & 1766.17 & $6.81^{\mathrm{bc}}$ & $450.35^{\mathrm{d}}$ & $85.54^{\mathrm{b}}$ & 1954.76 & $552.86^{\mathrm{b}}$ \\
\hline 0.5 & 1173.00 & 37.00 & 271.49 & 1385.36 & $7.03^{\mathrm{ab}}$ & $460.19^{\text {cd }}$ & $91.40^{\mathrm{b}}$ & 1947.22 & $515.18^{\mathrm{c}}$ \\
\hline 1 & 1197.31 & 35.55 & 285.95 & 1740.52 & $7.52^{\mathrm{a}}$ & $512.09^{\mathrm{ab}}$ & $95.63^{\mathrm{b}}$ & 1754.47 & $550.90^{\mathrm{b}}$ \\
\hline \multicolumn{10}{|l|}{ Order } \\
\hline 1 & & 35.59 & 274.01 & $1671.78^{b}$ & 6.87 & $471.80^{\mathrm{b}}$ & $95.64^{\mathrm{a}}$ & 1747.61 & $505.25^{\mathrm{d}}$ \\
\hline 2 & & 35.99 & 262.44 & $1819.02^{\mathrm{a}}$ & 6.89 & $540.33^{\mathrm{a}}$ & $97.85^{\mathrm{a}}$ & 1961.84 & $559.51^{\mathrm{c}}$ \\
\hline 3 & & 35.79 & 251.50 & $1834.22^{\mathrm{a}}$ & 6.93 & $459.26^{\mathrm{b}}$ & $91.39^{\mathrm{ab}}$ & 2016.27 & $584.97^{\mathrm{b}}$ \\
\hline 4 & & 36.16 & 247.09 & $1736.34^{\mathrm{ab}}$ & 7.01 & $449.49^{\mathrm{b}}$ & $91.31^{\mathrm{ab}}$ & 1938.90 & $580.31^{\mathrm{b}}$ \\
\hline 5 & & 36.29 & 269.00 & $1795.64^{\mathrm{ab}}$ & 7.26 & $448.48^{b}$ & $83.06^{\mathrm{b}}$ & 1895.37 & $595.86^{\mathrm{a}}$ \\
\hline \multicolumn{7}{|l|}{ Sex } & $83.36^{\mathrm{b}}$ & & $602.65^{\mathrm{a}}$ \\
\hline $\mathrm{F}$ & 1232.84 & $35.56^{\mathrm{b}}$ & 265.54 & 1798.76 & 6.99 & 489.07 & $94.45^{\mathrm{a}}$ & 1893.72 & $562.25^{\mathrm{a}}$ \\
\hline M & 1254.43 & $36.13^{\mathrm{a}}$ & 259.78 & 1790.80 & 6.94 & 484.33 & $89.04^{b}$ & 1883.35 & $556.08^{\mathrm{b}}$ \\
\hline \multicolumn{10}{|l|}{ Season } \\
\hline Dry & 1255.01 & 35.88 & 264.98 & 1802.62 & 7.03 & 518.13 & 97.29 & $1873.86^{\mathrm{b}}$ & 557.74 \\
\hline Rainy & 1239.87 & 35.83 & 261.39 & 1789.51 & 6.94 & 472.65 & 87.74 & $1948.8920^{\mathrm{a}}$ & 559.72 \\
\hline \multicolumn{10}{|l|}{ Year $^{1}$} \\
\hline 1970 & $1236.90^{\text {abcdef }}$ & $33.76^{\text {cdef }}$ & $293.75^{\mathrm{abc}}$ & $1728.10^{\text {bcdefg }}$ & 7.50 & - & - & $1781.90^{\mathrm{ab}}$ & 503.58 \\
\hline 1975 & $1194.29^{\text {bcdef }}$ & $34.45^{\text {cdef }}$ & $310.13^{\mathrm{abc}}$ & $1872.74^{\text {cdefg }}$ & 6.57 & 478.44 & 93.86 & $1866.35^{\mathrm{ab}}$ & 505.76 \\
\hline 1980 & $1252.65^{\text {bcdef }}$ & $34.83^{\text {abcdef }}$ & $282.94^{\mathrm{bc}}$ & $1548.19^{\text {cdefg }}$ & 7.21 & 477.25 & 89.43 & $1812.91^{\mathrm{ab}}$ & 504.22 \\
\hline 1985 & $1195.06^{\text {abcdef }}$ & $34.99^{\mathrm{abcdef}}$ & $243.81^{\mathrm{bc}}$ & $1811.90^{\mathrm{abcd}}$ & 6.71 & 436.17 & 86.97 & $2059.24^{\mathrm{a}}$ & 533.03 \\
\hline 1990 & $1156.07^{\text {cdef }}$ & $36.20^{\mathrm{abcdef}}$ & - & - & - & 442.33 & 89.85 & - & 574.21 \\
\hline 1995 & $1277.41^{\text {abcdef }}$ & $37.19^{\mathrm{abc}}$ & - & - & - & 532.94 & 95.75 & - & 579.69 \\
\hline 2000 & $1299.86^{\text {abcdef }}$ & $37.18^{\mathrm{abcdef}}$ & - & - & - & 479.12 & 91.95 & - & 597.99 \\
\hline 2005 & $1193.81^{\text {def }}$ & $36.36^{\mathrm{abcdef}}$ & - & $2214.66^{\mathrm{a}}$ & - & 606.29 & 97.64 & - & 580.85 \\
\hline 2010 & $1305.14^{\text {abcdef }}$ & $36.24^{\mathrm{abcdef}}$ & - & $1854.64^{\text {cdefg }}$ & - & 551.32 & 109.39 & - & 588.03 \\
\hline 2013 & $1205.53^{\text {bcdef }}$ & $35.22^{\text {abcdef }}$ & - & $1498.13^{\mathrm{fg}}$ & - & 651.69 & 75.00 & - & 550.18 \\
\hline
\end{tabular}

AFC: age at first calving, BW: calf birth weight, LP: lactation period, TMP: total milk production during lactation, F: fat milk percentage, CI: calving interval, SP: service period, P305: milk production corrected for 305 days, CW: cow weight at calving, ${ }^{1}$ data presented every five years. Different letters in the column differ statistically $(\mathrm{P}<0.05)$ by Tukey's test. 
Marques et al.
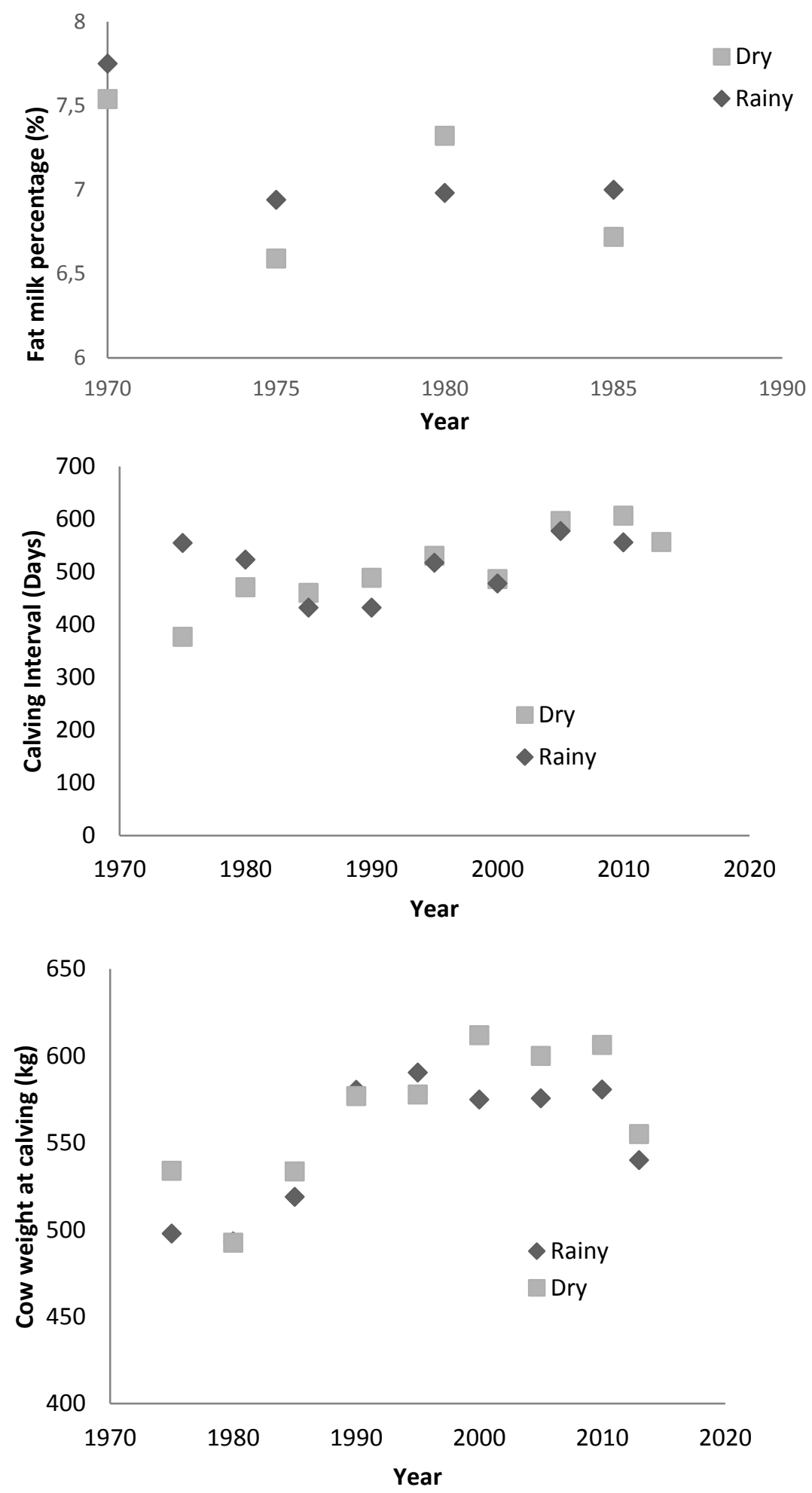

Figure 1. Interaction effect between year and season for fat milk percentage (A), calving interval (B) and cow weight at calving $(\mathrm{C})$ in dairy buffaloes reared in the Brazilian Amazon. 
The correlations between traits were in general medium to low (Table 3), with higher fat milk percentage associated with higher percentage of Murrah breed, longer lactation period and older cows, explaining $24.96 \%$ of the total variation
(Figure 2). Also, calf birth weight was positively related with the cow weight at calving. Total milk production was positively related with lactation period and cow weight at calving.

Table 3. Correlations between production traits in dairy buffaloes reared in the Brazilian Amazon

\begin{tabular}{|c|c|c|c|c|c|c|c|c|c|c|}
\hline & $\begin{array}{l}\mathrm{BW} \\
(\mathrm{kg})\end{array}$ & $\begin{array}{l}\mathrm{LP} \\
\text { (days) }\end{array}$ & $\begin{array}{l}\text { TMP } \\
(\mathrm{kg})\end{array}$ & $\begin{array}{l}\mathrm{F} \\
(\%)\end{array}$ & $\begin{array}{l}\mathrm{CI} \\
\text { (days) }\end{array}$ & $\begin{array}{l}\text { SP } \\
\text { (days) }\end{array}$ & $\begin{array}{l}\text { P305 } \\
\text { (kg) }\end{array}$ & $\begin{array}{l}\mathrm{CW} \\
(\mathrm{kg})\end{array}$ & $\begin{array}{l}\% \\
\text { Murrah }\end{array}$ & $\mathrm{O}$ \\
\hline LP & -0.06 & & & & & & & & & \\
\hline TMP & 0.07 & $0.59^{* *}$ & & & & & & & & \\
\hline $\mathrm{F}$ & 0.01 & $0.27 *$ & -0.04 & & & & & & & \\
\hline CI & 0.06 & 0.14 & 0.16 & -0.02 & & & & & & \\
\hline SP & -0.04 & 0.14 & 0.05 & -0.02 & $0.45 * *$ & & & & & \\
\hline P305 & 0.10 & $\begin{array}{l}- \\
0.23 *\end{array}$ & $0.58 * *$ & $-0.26^{*}$ & -0.05 & -0.05 & & & & \\
\hline $\mathrm{CW}$ & $0.29^{*}$ & - & $0.31^{*}$ & 0.00 & 0.15 & 0.01 & $0.44 * *$ & & & \\
\hline$\%$ Murrah & -0.08 & $0.23 *$ & -0.12 & $0.42 * *$ & 0.06 & 0.04 & $-0.27 *$ & -0.08 & & \\
\hline $\mathrm{O}$ & 0.02 & -0.08 & 0.00 & -0.01 & -0.16 & -0.11 & 0.13 & $0.36 * *$ & 0.05 & \\
\hline $\mathrm{AFC}$ & 0.03 & -0.07 & 0.05 & -0.02 & 0.03 & -0.04 & 0.13 & $0.45 * *$ & 0.13 & $0.92 * *$ \\
\hline
\end{tabular}

BW: calf birth weight, LP: lactation period, TMP: total milk production during lactation, F: fat milk percentage, CI: calving interval, SP: service period, P305: milk production corrected for 305 days, CW: cow weight at calving, O: order of birth, AC: age at first calving, *: $\mathrm{P}<0.05, * *: \mathrm{P}<0.001$.

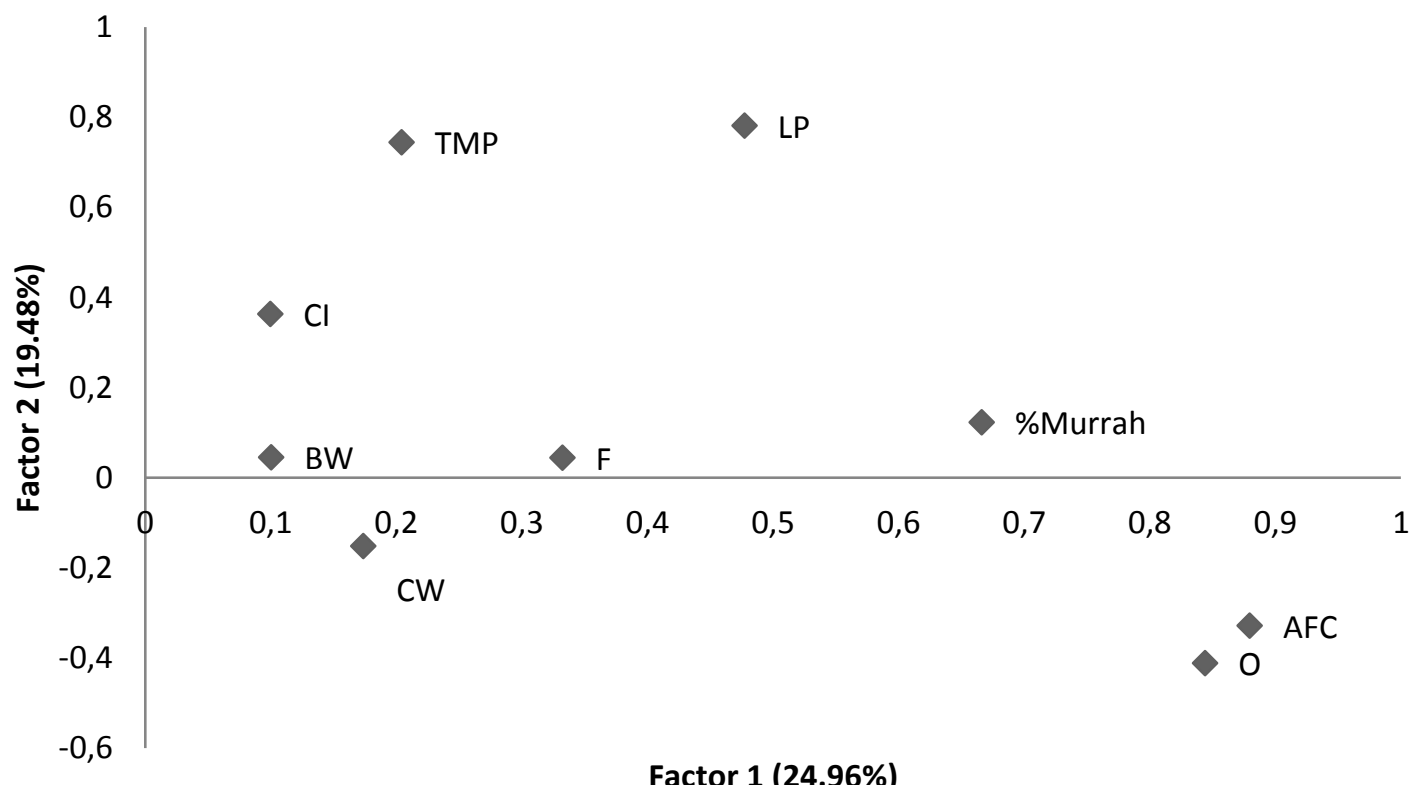

Figure 2. Principal component analysis for production traits in dairy buffaloes reared in the Brazilian Amazon. BW: calf birth weight, LP: lactation period, TMP: total milk production during lactation, F: fat milk percentage, $\mathrm{CI}$ : calving interval, $\mathrm{CW}$ : cow weight at calving, O: order of birth, AFC: age at first calving. 


\section{DISCUSSION}

Although there was no increase in production over the last years, the average total milk production during lactation (TMP) observed in this study was higher than the average of the national herd which ranges from 1,482 to $1,650 \mathrm{~kg}$ of milk (Tonhati et al., 2000a; Ramos et al., 2006; Rodrigues et al., 2010) and similar to the average of $1,830.81$ and $1,844.08 \mathrm{~kg}$ found in Brazilian summaries of Buffalo breeding programs - PROMEBUL (Ramos et al., 2004) and ABCB, (Programa..., 2007), respectively. These differences may be due to breed, production environment and feeding regime which vary widely over the country. The fat milk percentage $(\mathrm{F})$ results $(6.96 \%)$ confirmed the high fat content in the buffalo milk, a desirable factor for cheese production. This value was similar to those found by Fundora et al. (2001), Tonhati et al. (2000a) and Aspilcueta-Borquis et al. (2007) with average values of 6.98, 6.87 and of $6.85 \%$, respectively.

Age at first calving (AFC) averaged 41.14 months, similar to the average described by Rolim Filho et al. (2009) of 39.52 months. Despite this characteristic suffering intense environmental influence, the later age at first calving led the cow being more likely to be culled one year after the start of reproductive life, while early calving buffaloes were less likely to be culled and stayed longer in herds (Galeazzi et al., 2010). The higher AFC observed in this study may reflect management decisions, as well as nutritional and health limitations of the environment in which these animals were reared.

Gestation of the buffalo is around 310 days, so service periods (SP) close to 60 days are ideal for the production of one calf per year, reducing the calving interval (CI) closer to 12 months and obtaining a good reproductive management efficiency ratio. The higher SP observed in this study of 90.86 days may be due to longer lactation period or management factors reflecting in longer CI (483.99 days or 15.91 months). According to Cassiano et al. (2003) CI closer to 12 months is physiologically possible in buffaloes and economically advantageous.

Genetic group influenced fat milk percentage $(\mathrm{F})$, cow weight at calving $(\mathrm{CW})$ and reproductive characteristics such as calving interval (CI) and service period (SP), but had no effect on total milk production during lactation (TMP) and age at first calving (AFC). Murrah had the highest fat milk percentage between the genetic groups, with 7.52 $\%$. Most traits did not differ according to sex, except calf and cow weights as well as service period. Male calves were heavier and cows with male calves were lighter and had a shorter service period.

Season of calving is affected by climatic aspects which also affect vegetation and animal comfort. In some climatic types in the Amazon, there is rain almost all year round, with a season with heavy rain (January to June) and another where it rains less (July to December). Most traits were not influenced by season, except milk production corrected for 305 days which was higher in the rainy season. This may reflect greater pasture availability and therefore improved nutrition. According to Cassiano et al. (2003) reproductive characteristics were mainly determined by management, nutrition, climate and health in a given year, or certain periods, as well as management techniques and climate variations.

The largest influence $(\mathrm{P}<0.05)$ of order of birth was generally with primiparous females and older cows. This may reflect physiological immaturity at first calving and the use of cows beyond reproductive efficiency. In this case, cows can be kept up to the $13^{\text {th }}$ calving, with ages up to 20 years, reflecting problems with teeth and udder quality (Peeva and Ilieva, 2007).

Milk production increased in order of birth 2, and CI and SP were better from order of birth 3 and 5, respectively. Tonhati et al. (2000a) observed a milk production increase in order of birth 4 and $F$ from the 3rd order of birth. Sampaio Neto et al. (2001) also found differences $(\mathrm{P}<0.01)$ in milk production and $\mathrm{CI}$ from order of birth 5. Cassiano et al. (2003) also found effects of order of birth on CI and PS, buffaloes reaching their optimum productivity from 5 th to 7 th calving, later than what was found in this study.

Marques et al. (1991) found a high correlation between TMP and F (0.894) different from that found in this study which was negative and not significant (-0.04). As milk production increases there tends to be a decrease in fat milk percentage due to an increase in water content of the milk 
(Aspilcueta-Borquis et al., 2010). Both TMP and $\mathrm{F}$ showed low correlation with the reproductive efficiency, AFC and CI. Ramos et al. (2006) also found low correlation between milk production and CI (0.01), as well as Malhado et al. (2009) found negative correlations between TMP and AFC as well as TMP and CI (-0.15 and -0.02 , respectively). Positive correlations were found between cow and calf weights, as well as CI and $\mathrm{SP}$. The negative correlation between LP and CW meant that cows that were longer in milk tended to be lighter.

\section{CONCLUSIONS}

Production characteristics in dairy buffaloes reared in the Brazilian Eastern Amazon were significantly affected by management factors. This information can be used to help build sustainable production systems for the region and guide farmer decisions, because the dairy buffaloes can be raised for profit in the Brazilian Amazon.

\section{ACKNOWLEDGEMENTS}

To CAPES and CNPq for financing scholarships.

\section{REFERENCES}

ASPILCUETA-BORQUIS, R.R.; ARAUJO NETO, F.R.; BALDI, F. et al. Genetic parameters for buffalo milk yield and milk quality traits using Bayesian. J. Dairy Sci., v.93, p.2195-2201, 2010.

ASPILCUETA-BORQUIS, R.R.; TANAKA, A.; ALBUQUERQUE, L. et al. Genetic parameters estimate for milk, fat and protein yield analyzed by test day models for Murrah buffaloes in Brazil. Ital. J. Anim. Sci., v.6, Suppl.2, p.368-371, 2007.

BALDI, F.; LAUREANO, M.M.M.; GORDO, D.G.M. et al. Effect of lactation length adjustment procedures on genetic parameter estimates for buffalo milk yield. Genet. Mol. Biol., v.34, p.6267, 2011.

CASSIANO, L.A.P.; MARIANTE, A.S.; MCMANUS, C. et al. Caracterização fenotípica de raças bubalinas nacionais e do tipo Baio. Pesqui. Agropecu. Bras., v.38, p.1337-1342, 2003.

FUNDORA, O.; ROQUE, R.; SÁNCHEZ, R. Preliminary data on find behavior of grazing river
Buffaloes. Cuban J. Agric. Sci., v.35, p.13-15, 2001.

GALEAZZI, P.; MERCADANTE, M.E.Z.; SILVA, J.A. et al. Analysis of culling probability in diary buffalo using survival models. Animal, v.4, p.1325-1329, 2010.

MALHADO, C.H.M.; RAMOS, A.A.; CARNEIRO, P.L.S. et al. Parâmetros e tendências da produção de leite em bubalinos da raça Murrah no Brasil. Rev. Bras. Zootec., v.36, p.376-379, 2007.

MALHADO, C.H.M.; RAMOS, A.A.; CARNEIRO, P.L.S. et al. Estimativas de parâmetros genéticos para características reprodutivas e produtivas de búfalas mestiças do Brasil. Rev. Bras. Saúde Prod. Anim., v.10, p.830839, 2009.

MARQUES, J.R.F.; LOURENÇO JÚNIOR, J.B.; CARVALHO, L.O.D.M. et al. Parâmetros genéticos de características produtivas de búfalos (Bubalus bubalis) leiteiros. Belém: EMBRAPACPATU, 1991. 26p. (Boletim de Pesquisa, 123).

PEEVA, R.; ILIEVA, Y. Longevity of buffalo cows and reasons for their culling. Ital. J. Anim. Sci., v.6, Suppl.2, p.378-380, 2007.

PROGRAMA de melhoramento genético das raças bubalinas. São Paulo: ABCB/UNESP, 2007. 92p. Disponível em: <http://www.bufalo.com.br/adobe/melhoram_20 06.pdf $>$. Acessado em: 10 jan. 2019.

RAMOS, A.A.; MALHADO, C.H.M.; CARNEIRO, P.L.S. et al. Caracterização fenotípica e genética da produção de leite e o do intervalo entre partos em bubalinos da raça Murrah. Pesqui. Agropecu. Bras., v.41, p.12611267, 2006.

RAMOS, A.A.; WECHSLER, F.S.; ONSELEN, V.J.V.; GONÇALVES, H.C. PROMEBUL: sumário de touros bubalinos. Botucatu: UNESP/FMVZ, 2004. 39p.

RODRIGUES, A.E.; MARQUES, J.R.F.; ARAÚJO, C.V. et al. Estimação de parâmetros genéticos para características produtivas em búfalos na Amazônia Oriental. Arq. Bras. Med. Vet. Zootec., v.62, p.712-717, 2010. 
ROLIM FILHO, S.T.; RIBEIRO, H.F.L.; VALE, W.G. et al. Desempenho reprodutivo de fêmeas bubalinas criadas em sistema misto (várzea e pastagem artificial) no Estado do Pará. I. Idade a primeira cria, intervalo entre partos, época de parição, eficiência reprodutiva e taxa de prenhez. Cienc. Anim. Bras., v.10, p.754-763, 2009.

ROSALES, F.P.; BATALHA, M.O. Bubalinocultura no Estado de São Paulo: análise da competitividade do complexo agroindustrial do leite de búfala. São Paulo: Novas Edições Acadêmicas, 2017. 192p.

SAMPAIO NETO, J.C.; MARTINS FILHO, R.; LÔBO, N.R.B.; TONHATI, H. Avaliação dos desempenhos produtivo e reprodutivo de um rebanho bubalino no Estado do Ceará. Rev. Bras. Zootec., v.30, p.368-373, 2001.
TONHATI, H.; MUÑOZ, M.F.C.; DUARTE, J.M.C. et al. Parâmetros genéticos para a produção de leite, gordura e proteína em Bubalinos. Rev. Bras. Zootec., v.29, p.2051-2056, 2000a.

TONHATI, H.; MUÑOZ, M.F.C.; OLIVEIRA, J.A. et al. Test-day milk yield as a selection criterion for dairy buffaloes (Bubalus bubalis Artiodactyla, Bovidae). Genet. Mol. Biol., v.31, p.674-679, 2008.

TONHATI, H.; VASCONCELLOS, B.F.; ALBUQUERQUE, L.G. Genetic aspects of productive and reproductive traits in a Murrah buffalo herd in São Paulo, Brazil. J. Anim. Breed. Genet., v.117, p.331-336, 2000b. 